INTERNATIONAL JOURNAL FOR

HISTORY, CULTURE AND MODERNITY

www.history-culture-modernity.org

Published by: Uopen Journals

Copyright: @ The Author(s).

Content is licensed under a Creative Commons Attribution 4.0 International Licence

elSSN: 2213-0624

\title{
Islamic Tradition and Meanings of Modernity
}

\author{
Emin Poljarevic
}

HCM 3 (1): 29-57

URN:NBN:NL:UI:10-1-117065

\begin{abstract}
The debate about the compatibility of modernity and (the) Islamic tradition is, at this point, centuries old. This article analyzes some of its most recent expressions. The guiding question here is one about the meaning(s) of modernity and its impact on our general understanding of this particular religious tradition. We are often led to believe that this tradition is uniquely ill-equipped to absorb or make use of modernity's conceptual repertoire and its supposed liberating power. It therefore follows that the proponents of Islam and of liberalism are at odds with each other, primarily due to the assumption that they occupy different paradigms of understanding, knowledge, and even of hopes and aspirations. This article seeks to identify some elements of this, arguably erroneous, presumption by presenting an overview of several oft-repeated arguments related to modernity and Islamic ethics. Modernity, as it relates to shifting public conceptions of freedom in Muslim-majority societies, has proven to have tremendous mobilizing power. Social actors continuously contest such ideas as freedom, religion, and related issues in the realm of civil society. One such discursive shift underway is the 'Arab Spring', arguably one of the strongest indicators of the ongoing process of modernity within Arab societies on multiple levels - a process that is deeply unsettling and entirely open-ended in terms of cultural and socio-political outcomes.
\end{abstract}

Keywords: Islamic tradition, modernity, Muslim ethics, religious revival, alternative modernities

Review of: Muhammad Abed al-Jabri, The Formation of Arab Reason: Text, Tradition and the Construction of Modernity in the Arab World, 
trans. The Centre for Arab Unity Studies (New York: I.B. Tauris, 20 I I), 462 pp., ISBN: 978-I-84885-06I-3; Wael B. Hallaq, The Impossible State: Islam, Politics, and Modernity's Moral Predicament (New York: Columbia University Press, 20 I3), 256 pp., ISBN: 978-0-23 I-I6256-2; Samira Haj, Reconfiguring Islamic Tradition: Reform, Rationality, and Modernity (Stanford, CA: Stanford University Press, 2009), 284 pp., ISBN: 978-0-8047-7860-2.

\section{Introduction}

This article analyzes part of the ongoing debate about the relation between modernity and Islamic tradition ${ }^{1}$ through three recent works on the reform of Arab reason, the Islamic state, and the impact of modernity: Muhammad Abed al-Jabri's (d. 20Io) The Formation of Arab Reason: Text, Tradition, and the Construction of Modernity in the Arab World (20 I I); Wael B. Hallaq, The Impossible State: Islam, Politics, and Modernity's Moral Predicament (2013); and Samira Haj, Reconfiguring Islamic Tradition: Reform, Rationality, and Modernity (2009). Al-Jabri, a Moroccan philosopher, holds that modernity signifies a rational representation of both scientific and cultural progress. Hallaq, a scholar of Islamic law of Palestinian origin, describes modernity through a legalanalytic lens as a process of moral regression or a transformation of one kind of political system into another. Haj, a historian of Palestinian origin, presents a historical thematic explanation of the connection between the Islamic tradition and modernity. As a matter of clarification, it is useful to highlight exactly what the Islamic tradition means, as this notion will be used throughout this article. As presented by Haj and Hallaq, and less so by al-Jabri, this term refers to an eclectic set of discourses (with a specific set of metaphysical doctrines) that emanate from the Qur'an and the codified hadith texts, ${ }^{2}$ are held together by Islamic theological principles rooted in a strict ethical monotheism, and manifested through a range of individual and social practices. ${ }^{3}$

Their separate attempts to approach, define, and understand modernity in the background of Islamic tradition reveal much of the complexity of contemporary Muslim discourse. In many ways, these scholars represent different streams of thought embedded within the longsimmering debate and reveal the difficulty in separating 'faith-based 
reasoning from public reason' ${ }^{4}$ Although the ensuing apparent tensions do not demonstrate the process of modernity, they certainly signal some of its more apparent effects. It is within this very activity that sociocultural and political actors find themselves striving for dominance and control of resources and power.

Tradition represents a discursive convention, including a pool of values, comprised of cultural concepts and practices wherein 'an adherent of a tradition is always to enact some further stage in the development of one's tradition'. ${ }^{5}$ The pace and direction of a tradition's change is a process within which the struggle for power and control of the real and the symbolic occurs. If modernity is not the defining feature, then it is at least a critical part of this process for it is disruptive and plays a role inside the power struggle for control of the direction towards which the process evolves. Therefore, modernity should be understood as being more organic and malleable than the liberal notion of modernity and its claim of universality. ${ }^{6}$

The basic premise here is that modernity is fundamentally concerned with freedom, be it social and/or individual. Thus as one of its stated fundamental elements, freedom is not only concerned with an individual's materialistic freedoms and prospects of social mobility, but also closely connected with the ethical and moral concerns of social groups. ${ }^{7}$ This notion goes beyond discussions on the limits of freedom, ${ }^{8}$ for it touches upon such concepts as negative and positive freedom. ${ }^{9}$ With this in mind, the argument that many Muslim-majority societies, regardless of 'the extent of their difficulties and shortcomings, are modeled on a worldview that attaches great importance to spirituality and community' differs somewhat from these arguments related to more secularized societies. ${ }^{10}$ As a result, the epistemological frameworks of freedom and their mobilizing potential differ slightly in these distinctive socio-cultural contexts.

The three authors, who seem to be aware of these nuances, nevertheless understand modernity as a form of rupture with the past, one that signifies the now. In their view, modernity, at its broadest, accentuates the uniqueness of the human condition; it creates the worship of the new and replaces the worship of the old. However, their understanding and normative outlooks on modernity vis-à-vis the Islamic tradition are not the same, as will become more apparent in the following sections. 
Al-Jabri presents modernity as a rational representation of both scientific and cultural progress. For him, it represents a fundamental rupture between the old enchanted world and the new scientism, as well as the cultural progress and humanism initiated and achieved (so far) only by Europeans. Although he recognizes that Arab-Islamic civilization embarked on the path of modernity via its partial adoption of classical Greek philosophy, the project ultimately failed. He is therefore concerned with the epistemological question of why Arabs discontinued their path toward progress, liberation and, most importantly, objectification of European science. In other words, he understands modernity as something initiated outside the cultural realm of Muslim-majority (incl. Arab) societies, and therefore inaccessible to Muslims as long as they cling to the Islamic tradition. The book, which is clearly only the first part of his unfinished treatise on Arab reason and modernity, gives only an inconclusive account of his broader argument.

For Hallaq, modernity symbolizes the invention of another type of social structure and source of political authority. Here, we can recognize the break-up of ethical certainty and the loss of moral accountability, something that is particularly accentuated in Muslim political discourses. On top of this is a by-product of modernity, namely, liberalism, which strives to universalize its principles and therefore opposes all forms of intellectual heterodoxy - including the Islamic tradition. Moreover, the modern nation state represents a structural unity in which power is distributed through and with the appropriate branches of authority. ${ }^{\mathrm{II}}$ Hallaq argues that such a structural unity neither existed nor developed in pre-modern Muslim polities. ${ }^{12}$

In Haj's book we can recognize the Saidian critique of the effects of this relation. Her analysis of modernity's various intellectual effects in several Muslim-majority contexts challenges modernity's binary representations by emphasizing colonialism's historical effects on them: 'modern vs. traditional', 'East vs. West', 'rational vs. irrational', and so on. Instead, she presents historical Muslim figures and events as being closely interfaced, thus bringing the past to life in a more critical and progressive manner in order to substantiate the contention that Islam is a living tradition that has passed through many phases. She views two of these phases as the most prominent and thus explores their lifework: the Hanbalite scholar Muhammad Ibn 'Abdul Wahhab (d. I787) and the Egyptian mufti Muhammad 'Abduh (d. I905). She 
does this in a parallel fashion to reveal their common and diverging features and thereby reflect on how modernity has impacted Arab-Muslim scholarship.

Modernity, as it relates to the broad meaning of Islamic tradition presented in these three books, can be described as a transgressive cultural process with a high potential for social and ideological reinvention. One part of the critique of modernity, as that concept is broadly understood in the western academic tradition, ${ }^{13}$ is centred on its debatable inability to convincingly explicate social and cultural change in many traditional Muslim societies. One aspect of the various critical approaches is just what exactly this particular term means. Its proponents associate it with various principles (e.g., solidarity and secularization) and thus oppose all organized calls for a public morality rooted in religious traditions. ${ }^{14}$ On the other hand, the Frankfurt School and other critics are more sceptical of what they see as a process that instrumentalizes human relations.

This article seeks to clarify the components of this overarching discussion by contextualizing the question of whether modernity has been aborted, reconsidered, or transcended. In consequence, it examines the impact of modernity's unsettling forces through an analysis of these three scholars' publications. In the tradition of the modernity - Islam debate, ${ }^{15}$ the rest of this article explores normative (Islamic) ethics, which are the basis for socio-cultural morality and even of the rule of law, by contrasting some of their arguments related to ethics. Special attention will be paid to reason, law, and revival.

\section{Ethics between Thought and Reason}

Ethics are ultimately concerned with the quality of one's moral life. On a basic level, they represent subjective assessments of human actions. The Islamic tradition often formulates ethics through a discussion of 'halal' and 'haram', including all of these terms' existing nuances. The primary sources of its ethical epistemology, the Qur'an and Sunnah, contain core ethical guidance, direction, and inspiration of virtuous behaviour. ${ }^{16}$ In the tradition's praxis-oriented part, therefore, ethics are loosely divided into 'ibadat (worship) and mu'amalat (social relations), both of which are interdependent and conceptually intertwined. For instance, the Ottoman-Tunisian modernist Khayr al-Din al-Tunisi 
(d. I 890), much like the North African social historian Ibn Khaldun (d. I406) and the Syrian legal scholar Ibn Taymiyya (d. I328), contended that the moral order of the society and the state, as well as the power relations between them, ultimately depend upon the ethical order provided by the rich legal history of Islamic jurisprudence. ${ }^{17}$ Herein, one understands that the high personal commitment to ethical (i.e., religious) principles is interwoven with socio-political ethics (viz., conceptually difficult to separate).

Al-Jabri bases his argument concerning ethics on his strict distinction between the West and the Arab world's epistemic frame of reference: '[T]here is a major difference between an orientation proceeding from knowledge to ethics and an orientation proceeding from ethics to knowledge. In the first case, which is that of Greco-European [i.e. Western] thought, ethics are based on knowledge, whereas in the second case, the case of the Arab thought, knowledge is based on ethics' ${ }^{18}$ This assertion leads him to conclude that Arab reason is manifestly retrospective (i.e., depraved), primarily because of its dependence on the established cultural reference frame belonging to the 'Era of Codification'. He views this as one of the major reasons why Arab culture failed to stimulate a European type of modernity. Reason, alJabri claims, is separated from the more generic terms, such as thought and ideology. Thought is the content or product of a more systematic deliberation, whereas reason is the central instrument of modern intellect or, for that matter, of any long-term scientific progress. ${ }^{19}$

Instead of dwelling upon the particular features of such differences, al-Jabri postulates a long string of causes behind the different levels of effectiveness of these two distinct types of reason. The exposed differences ultimately depend on 'the referential system formed by the essential coordinates of the defining elements and of this culture and its components, and, at the forefront of these, cultural heritage and social environment and perception of the future, and even the perception of the world, the universe and the human being, as determined by the components of that culture'.$^{20}$ Although he recognizes the universality of reason in its overarching configuration, he asserts that reason can manifest its instrumental function only within a given culture. ${ }^{21}$

More broadly, al-Jabri attempts to construct a critical epistemic model by which to view and understand the particularities of Arab reason. ${ }^{22}$ First, he locates it in a specific time and place: as trapped in 
the 'codification' of pre-Islamic and early Islamic values and cultural norms. Thus the Arabic language became the container of Arab consciousness and was subsequently set apart from other cultures. ${ }^{23}$ In large part, he sees this process as a major contribution to the 'resignation of the [Arab] reason' that subsequently resulted in Arab civilization's loss of leadership during the fifteenth century. ${ }^{24}$

Second, much like his understanding of Arab reason, his explanatory model leads him to conclude that the pre-modern Arab community's codification of knowledge eventually ended the production of knowledge. ${ }^{25}$ After all, early Muslim scholars were anxious to canonize the Qur'anic text, categorize the Hadith literature, sacralize early historical events, formulate methods of jurisprudence, and so on. As much as this postulate might resonate with our secular interpretations of religious doctrine (Islamic or otherwise), it is nevertheless problematic. For example, this line of reasoning leads al-Jabri and others who agree with it to consider 'Arab cultural history [as] stagnant' mainly due to the religiously ordained public docility. This perspective could be supported by arguing that the contemporary 'Arab thought' is seen as a venue in which 'old' ideas and values are repackaged and sold, as it were, in a market of other stagnant ideas. ${ }^{26}$ But such an analysis does not reflect the Arab world's diverse realities, if the term 'Arab reason' is meant to include the cultures stretching from Iraq to Morocco, for this region's diversity, in terms of literature, art, social criticism, and innovativeness under political repression, transcends al-Jabri's framework of good and evil. ${ }^{27}$ While this does not cancel the importance of his critique, it does subject many of his conclusions to question.

A more relevant point concerns the core idea of Arab reason as an operational mechanism. This idea postulates that the mechanism by and through which Arabs, and for that matter all other ethnic cultures, produce thought (viz. knowledge) is ensnared in historically welded traditions and thereby defined through archaic procedures. Despite the exceptionally broad and intense presentation he makes to support his thesis, al-Jabri's argument is troubling for several reasons. First, he claims that 'Arab reason [had] remained a prisoner of the production of this period' (i.e., the Era of Codification) due to Arabic's linguistic nature and the Islamic tradition's critical dependence and reliance on the text (i.e., the Qur' an and Sunnah). ${ }^{28}$ As such, it remains a prisoner of a stagnant scientific method largely because the Arabs could 
not refurbish classical Greek logic into a durable system of reasoning about the natural world. ${ }^{29}$ Second, he implicitly states that their failure to do so caused the Islamic tradition to stop progressing after 'the door of ijtihad' (textual reinterpretation) was effectively closed (ca. eighth/ ninth-century $\mathrm{AH}$ ) and legitimized the blind following of established jurisprudential traditions that eventually minimized free thought and critical reasoning..$^{30}$ According to him, this explains why much of the intellectual and religious debate has revolved around the use of Arabic, its syntax, and the proper meaning of words even down to our own day.

Nevertheless, the power of the Arabic-language Qur'an, as well as its claim to be God's revealed speech and its universal moral message as the annex to previous revelations in the Abrahamic tradition, resonated well with the premodern peoples of the Middle East. However, the Islamic tradition that evolved from these rudimentary notions exceeds al-Jabri's concept of Arab reason. The original Arab-Muslim empire was massively influenced by non-native Arab-speakers as its borders continued to expand in all directions..$^{31}$ Even though these non-Arab Muslim scholars were gradually trained in Arabic and Islamic doctrines, their cultural traits inevitably reshaped the initial 'pure' Arab reason. ${ }^{32}$ This fact alone raises doubts about the preamble of al-Jabri's claim that the Arabs' pre-Islamic Bedouin culture, with all of its benefits and limitations, was the basis of Arab reason in the first place. Although this does not take away from the fact that Arabic remains central to Islamic scholarship, it does problematize the assertion that language cannot be transformed or that a concept's meaning does not shift over time.

Hallaq pursues this path by illustrating the process that enabled Sunni theologians and jurists to be surprisingly progressive as regards the types of questions they were asking already in the eighth century. What initially started as a vigorous intellectual debate between traditionalists and rationalists had, two centuries later, developed into 'the Great Synthesis' out of which succeeding generations of religious elites continued to develop a range of methods of interpretation. The crux of this synthesis, according to him, was the synchronization of revelation and reason, a consequence of the conscientious evolution of legal and intellectual discourse as related to ethics. ${ }^{33}$

Al-Jabri's more abstract argument starts by distinguishing the Arab domain of reason from its classical Greco-European counterpart. In his words, two epistemological traditions exist and, quite naturally, 
produce different roles for ethics. Arab reason seemingly lags behind what he calls the 'Greco-European mind' primarily because it cannot reformulate its core ethics. This assumes that the knowledge-production processes found in these two traditions are radically different. Here, alJabri is clearly an idealist who follows Georg Hegel's (d. I83I) line of thought. ${ }^{34}$ As noted previously, normative ethics constitute the diving force behind knowledge accumulation in the case of Arab reason; in the Greco-European case, however, ethics is based on knowledge and therefore generated by correlating observable natural events with reason in nature. Arab reason, which constructs knowledge only to gather information about the world, is based on the primacy of Islamic ethical principles that ultimately seek to 'prove' the preordained (viz. Godgiven) notions of good and evil. ${ }^{35}$ It seems that in the European context the idea of God has functioned as a mere " assistant" to human reason in uncovering the natural order'. ${ }^{36}$ This statement contradicts al-Jabri's previous claim that Arab reason is fundamentally shaped by revelation, which holds that nature helps humanity understand God. If this proposition is true, then it reveals a very fundamental difference indeed.

This tripartite relational model of God, nature, and humanity as the most distinct elements reveals al-Jabri's philosophical post-mortem. ${ }^{37}$ Grounding himself in this framework, he proposes that if Arabs are serious about progressing in their thought, then they need to pay the proper attention to Arab reason in order to produce enough intellectual capacity to ignite and support a more progressive notion of (Arab-Islamic) modernity. This core idea seems to represent al-Jabri's metaphysics of cultural and scientific progress. But as we have seen, Islamic jurists engaged in a constant process of substantive reasoning about law and ethics. After all, legal systems do entreat methodological consistency based on innovative reasoning to resolve increasingly complex and demanding socio-political challenges. ${ }^{8}$ This realization, among other things, indicates a living religio-ethical tradition, as demonstrated in Hallaq's work, ${ }^{39}$ and hence one that is far more dynamic than what alJabri would have us believe. ${ }^{40}$

The Islamic tradition, understood as a set of living discursive traditions, has passed through multiple formative stages and therefore has been shaped by centuries of scholarly debates and conflicts. To various degrees, this can be said of all religious, cultural, and political traditions. Al-Jabri states this, but for some reason still insists that the 
doors of ijtihad were closed after the 'Era of Codification'. Then again, perhaps this assertion is not so remarkable if one considers that much of his argument concerning the atrophy of Arab 'reason' rests on the postulation that mechanisms of reasoning have been imprisoned by the past (i.e. revelation). ${ }^{4 \mathrm{I}}$ One obvious piece of evidence that disputes this is the work of Ibn Tamiyyah (d. I328), who in many ways defined the direction of the Sunni ijtihad tradition's trajectory. However, this does not mean that he also defined its content, as some would have us believe..$^{42}$ In fact, his great jurisprudential flexibility and competence enabled him to challenge theological heterodoxy, including the influence of classical Greek philosophy on Islamic disciplines. ${ }^{43}$ Another example is al-Shatibi (d. I388), whose framework of Islamic normativity (i.e., Shari'a) and classification of ethical segments set an indelible mark on the subsequent branches of the Islamic legal tradition. For instance, his tripartite arrangement of the Shari'a's ethical guidelines, 'compelling necessity', 'needs', and 'improvements' ('of ethical directives') continues to serve as the basis for contemporary legal debates among Muslim jurists. ${ }^{44}$ Another and more important piece of evidence against this supposed closure is the fact that jurisprudence (fiqh: the ethics of action) cannot function without it, given that the entire basis of Islamic legal theory (usul al-fiqh) rests upon the Islamic scholars' ability to reinterpret the source texts. Despite Islamic scholarship's weakening (ca. 900), at least in the context of its creative approach to (re) producing religious knowledge, the importance of ijtihad as a fundamental scholastic exercise did not diminish to any significant extent. ${ }^{45}$

In sum, al-Jabri's approach is based on a highly structuralized set of presuppositions that supports the thesis of strict path-dependency, due to his selective consideration of historical events, for example, the evolution of the intellectual movement of Islamic scholars. It is hard to accept Arab reason's postulated ethical uniformity, homogeneity, and even reality, just as it is implausible to imagine other specified types of reason. This argument is similar to that of Aziz al-Azmeh's dismissal of Islamic tradition and contemporary attempts of Muslim revivalism as 'anti-Enlightenment' and therefore its incompatibility with modernity. ${ }^{46}$

Reason is after all the universal human ability to organize our sensory inputs about the world and then formulate thoughts and ideas about them. As cultural differences are a reality, it is therefore not hyperbolic to ask to what degree and in which ways reason can be defined as 'Arab' 
or otherwise. It is through various processes (e.g. intellectual, cultural, political, economic etc.) of contestation between the cultural reservoir of values (i.e. tradition), external cultural influences, and the creativity of the human (including the Arab) mind that we find an immense diversity of potential outcomes of the socio-political evolutionary process. The religious tradition is certainly a part of this process, but is by no means its dominant element. Expressed differently, we can observe within the ever-changing public sphere the non-static or non-unilateral transformation of civil society regardless of the level of socio-political control and repression dominating the Middle East and North Africa. ${ }^{47}$ In this regard and despite some stimulating insights, al-Jabri's analysis is too restricted to capture the broad spectrum of competing narratives in what can be described as the Arab intellectual tradition.

It is perhaps so that I do not understand the particularities of the Arab reason as defined by al-Jabri. My inability might somehow depend on the fact that I am not an Arab and thereby not familiar with the "Arab reason's' unique framework. If that were the case, my analysis of his argument would render my critique irrelevant. Nonetheless, it seems to me that al-Jabri's line of argumentation, both by its intent and by its form, obstructs the constructive exchange of cross-cultural insights and effectively thwarts the way forward in socio-cultural and political transformation of the post-Arab Spring world.

\section{Through a Glass Darkly: Ethics and Law}

Modernity's principal idea has been, and in many ways still is, that 'traditional' religion, defined as a general framework for understanding the world and as a dogmatic guide for humanity, is largely defunct and irrelevant in our contemporary world. Al-Jabri seeks thus to relocate the Arabs' affinity for Islamic dogmatism toward more 'progressive' notions of positivism and science. Fully aware of the difficulty of inciting a clean break between the secular and the traditional Islamic methods of reasoning, he attempts to deconstruct and render defunct Arab (i.e. Islamic) reason. Hallaq, on the other hand, seeks to problematize the premises of this supposed incongruity by exploring the particularities of modernity's own moral predicament. The discourse and the assumption of modernity as progress are scrutinized, and with 
it the Islamists' mission to establish an Islamic state. Al-Jabri, as noted above, reaches a similar conclusion but for very different reasons.

Hallaq's opening claim is that the Islamic tradition is essentially incompatible with the concept of the modern nation state because the latter is a product of a particular metaphysics that is loaded with a range of historically contingent systems of communication, reasoning, and socio-political interactions. He further asserts the 'fact' that all of these differ significantly from the Islamic tradition, which has its own unique set of metaphysical certainties. Although he recognizes the possibility of modification over time within both realms of metaphysical purviews, ideals of Islamic morality and socio-political realities of state building are intensely dissimilar. ${ }^{48} \mathrm{~A}$ great deal of his argument on morality and its particularities is built on the work of those who critique a westerncentred notion of modernity's ideological product, liberalism, namely the moral philosophers Alasdair McIntyre and Charles Taylor, the legal theoretician Carl Schmitt, and others.

According to Hallaq, Islamic governance followed its own path and developed around the idea of the Shari'a, represented as the divine set of legal principles. As such, he notes, '[t]here can be no Islam without a moral-legal system that is anchored in metaphysics; there can be no such moral system without or outside divine sovereignty'. He then adds that 'at the same time, there can be no modern state without its own sovereignty and sovereign will', in order to demonstrate the paradox between the core idea of Islam and the nation state. ${ }^{49}$ In many ways, his evaluation of the modern state is based on Schmitt's conception of the liberal state, in which the individual is 'detached, isolated, and emancipated [where he/she becomes the middle point, the court of last resort, the absolute]'.$^{50}$ The structure of the Shari'a, on the other hand, represents the rule of law as rooted in a 'moral-legal ethic' based upon the idea of God's sovereignty, which was pervasive in all Muslim communities..$^{51}$

In relation to the law, Hallaq claims that the question of "why be moral?' is irrelevant for the legal tradition that developed in the European context. As Europeans 'disenchanted' the world and lost the sense of divine omnipotence, modernity shifted its attention from what 'ought' to be to what 'is'. It can therefore be argued in broad terms that morality, or 'value', gave way to 'fact' and the instrumentality of reason became the norm by which all things were judged..$^{52}$ This process, as he 
points out, is historically and spatially contingent upon the European context and therefore cannot be - nor should it be - universally replicable. ${ }^{53}$ This is a useful point when one tries to scrutinize the subjectivities of a cultural framework (e.g., the Islamic tradition) and its socially constructed normativity (e.g., Islamic jurisprudence). Hence, it is reasonable to claim that in today's societies the subjectivities of a given culture influence the social morality underpinning communal rules and relations and subsequently shape the characteristics of the moral fabric of law. Hallaq challenges the usefulness of the modern socio-political framework for human wellbeing.

For instance, the split between what 'is' and what 'ought to be' or the question of 'why be moral?' were never posed within many of Islam's traditional discourses, for being 'moral' was always an essential part of the 'law'. Thus, as it was 'too obvious to Muslim legists to warrant much reflection [on why be moral] on their part, our question must be: How was the moral subject fashioned? The immediacy of this question stems from a reality in which law fed on morality, in its multi-layered social constitution'. ${ }^{54}$ In a way, Hallaq turns al-Jabri's argument on its head by discussing morality, law, and political organization, thereby concretizing a part of the latter's epistemological argument. Hallaq understands what al-Jabri sees as the Islamic tradition's prison is actually its centre of gravity; in fact, not as a prison, but as a socio-ethical construct that is worth exploring further and therefore preserving.

In part, this assumption serves as the basis of his central assertion: The modern state, a by-product of modernity as well as a sovereign entity in and of itself (e.g., it answers to no one, has coercive power to implement its rules, and so on), is by definition, an antithesis of the constructs of collective morality - including the Islamic tradition, in which sovereignty rests with the Creator - by the sole fact that these two phenomena are rooted in radically different worldviews. ${ }^{55}$ The contemporary world's dominant political and socio-cultural structure is based on the ideas of the Enlightenment: The liberal idea of 'progressive improvement' demands conformity to the universalist vision of modernity wherein we find 'a homogeneous teleological structure' that inevitably guides all cultures toward progress, i.e., 'Western modernity'. ${ }^{56}$ Hence, any challenge to this particular idea of progress inevitably unleashes the protective measures of the powerful representatives 
of 'progress', since the 'logic' of progressivism does not tolerate rival streams of thought.

Hallaq's analysis separates two types of sovereignties: that of the modern state and that of the Divine, each of which demand the social actors' idiosyncratic consideration of the rule of law. This assumed idiosyncrasy also includes the actors' sensitivities as regards different understandings of the social role of ethics and how they relate to the legislative process. For instance, throughout most of Islamic tradition's history, 'the paradigmatic moral force of the Sharī'a ..., compelled judges and rulers alike to respect judicial independence'. ${ }^{57}$ Hence, the notion of judicial independence is an integral part of the rule of law, which lies at the core of the Islamic tradition. Expressed differently, the multivariate relationship among cultural tradition, ethics, and law has essentially been the core of the living tradition, viz. Islam. The Shari'a's historically constructed ethical framework embodies the religious tradition and thereby gives content to what it means to be Muslim..$^{8}$ This is certainly at odds with our idea of the modern state, which has been constructed on 'the fictitious concept of will to representation'. This will is assumed to be rooted in 'the idea that the nation ... is the sole author of its will and destiny'. Hallaq therefore argues that the state is constructed within a historically contingent period and duly within the European context. ${ }^{59}$ Clearly, this particular ethical framework is not rooted in the experiences of the Islamic tradition. But this is not the same as accepting the existence of an inevitable conflict and zero-sum game when different core traditions interact with each other, even though the argument might suggest this.

If we limit ourselves to looking at the implications of the modern state as regards the socio-political arrangement(s) of traditional Muslim-majority societies, we can find some important discrepancies and tensions. And yet this does not mean that one tradition should be considered superior to another tradition, but only that such disparities cause significant socio-political tensions in parts of the Middle East and North Africa. This is primarily seen when some Muslims attempt to synchronize these two judicial traditions, each of which is rooted in a different conception of sovereignty. For example, we can think of the tenacious insistence with which many Islamists claim that the modern state can be used to achieve the Islamic tradition's 'objective': to establish the Creator as the source of sovereignty. This mode of thinking is 
based on the perception that the state exists to implement a particular ideology and is therefore not an institutional imperative based on a set of normative assumptions.

Max Weber describes this tension between religion and the dimension of human interactions as 'the intellectual sphere' within which apprehensions about ethics are both expressed and in unremitting discursive flux. ${ }^{60}$ For example, one such apprehension is grounded in the economic policies of some Islamist political parties. So far, it seems that 'the dominant Islamist approach to the economy, with minor variations, is free-market capitalism. In Egypt, Tunisia and Morocco, the Brotherhood, Ennahda and the Justice and Development Party [respectively] have shown great interests to deal with global financial institutions like the International Monetary Fund and the World Bank'. ${ }^{61}$ Although free-market capitalism is certainly not rooted in the Islamic tradition, it nevertheless serves as the basis for the financial policies of major Islamist groups.

Another concern has been their call for the restrictions on sales of alcohol, which would inevitably affect the flow of European tourists to both Egypt and Tunisia. ${ }^{62}$ Similar tensions are plentiful, for two parallel paradigms of thinking about the human condition and sources of sovereignty cannot meet. In fact, any attempt to 'bend space' so the parallel paradigms can somehow 'meet' will ultimately create significant apprehension in both Muslim and non-Muslim majority communities.

Even if Shari'a-bound institutions and their hermeneutics have suffered primarily due to the pressure of (neo)colonialism, Hallaq argues that their moral system is 'a capital of immeasurable value'. ${ }^{63}$ This is where al-Jabri and Hallaq branch off into diametrically opposite directions. Instead of debunking the Islamic tradition, after explaining how the state (one of modernity's most tangible products) is incompatible with this same tradition, Hallaq explores a possibility in which the Shari'a, with its moral and ethical conventions, can mend some of modernity's more ominous effects. ${ }^{64}$

For instance, the metaphysical assumption upon which the state rests is directly concerned with 'its will to power' and the subordination of everyone within its realm of control. This assertion, as well as the underpinnings of positivism that serve as the methodology of state power, are, as Hallaq amply notes, incompatible with Islamic governance. This consideration goes back to the issue of the foundation of 
sovereignty and thereby to the rule of law. He goes on to say that morality, as the principal guide of individual and collective actions, ought to be independent from positivism and, consequently, be anchored in moral principles other than 'earthly sovereignty', viz. 'transcendent morality'. In this way, transcendent morality can have a real potential to protect humanity from political tyranny, socio-cultural oppression, economic subjugation, and so on, due to its independence from the sovereign will that 'represents an inner dialectic of self-constitution' ${ }^{65}$

The Shari'a's value seems to reside in its ability to generate enough socio-cultural counter-pressure to resist the pressure of the liberal claim of universalism that has, in more ways than one, displaced morality in times when moral decisions are required. ${ }^{66}$ Hallaq's analysis, despite being centred on morality as a matter of contention between the modern (liberal nation) state and the Islamic tradition, could - and should - be considered in the wider context of the debate on whether morality extends beyond Muslim communities and conventional liberal and capitalist polities. This is a radically different approach to the Islamic tradition's analytical tradition and its relationship with modernity. ${ }^{67}$ Hallaq's critical analysis takes into account a constructive potential of the Islamic tradition's moral dimensions (e.g., Shari'a, fiqh etc.) to contribute to the well-needed moral recovery of the broader project of modernity. He does this by adding a valorizing feature to the global intellectual discourse through implicitly probing into what it means to develop, evolve, and improve. This is an inventive approach, even though we do not find an actual road map on how this moral recovery ought to take place.

\section{Ethics of Revival and Reform}

Samira Haj's text concretizes the main theme of the earlier discussion by analyzing the work and legacy of the Najdi Hanbalite scholar Muhammad Ibn 'Abdul Wahhab (d. 1787$)^{68}$ and the Egyptian mufti Muhammad 'Abduh (d. I905) in a parallel fashion. Both of these reformers' scholarship developed amidst specific cultural, political, and social circumstances and was, quite naturally, heavily informed by the surrounding dynamics. Haj insightfully ignores the question of whether Ibn 'Abdul Wahhab was violent or not - and there is much to be said for either assumption - and instead focuses on the more pertinent issue: 
What was the purpose and nature of his revivalism in the heart of the Arab Peninsula and beyond? For instance, she explores multiple sets of claims, assumptions, and analogies in order to problematize the mainstream understanding of his scholarship as a zealous, violent, irrational, and ultimately destructive figure. ${ }^{69} \mathrm{~A}$ century later in Egypt, 'Abduh's revivalism would have an immense impact on the emerging revivalist/ reformist movements both at home and abroad. Other than the obvious contextual dependency that determined which kinds of questions they raised, one common issue linked them: the status of knowledge and its implication for the living tradition.

In eighteenth-century Najd, Islamic knowledge was - and in many ways remains - constituted by scripturalist reading(s) of the Qur'an and Sunnah as well as the major works of the early (pre-modern) jurisprudential scholars. These canonized works were passed down the generations through a strict process of personal tutoring that depended upon memorization and accreditation by the relevant authority (viz., the ijazah system). This classic isnad system of knowledge transmission continues to be promoted by many contemporary Salafi groups and Sufi orders. Thus, one can say that knowledge has been pre-approved and therefore preserved from any 'corruption' that can be traced back to the unauthorized mind. Najd's socio-cultural context and traditional mode of interpersonal relations functioned through a system of narration, which was considered to be the most pristine method of preservation. Ibn Abdul Wahhab perceived the intruding religious heterodoxy promoted by the Ottomans as a direct infringement on Islamic orthodoxy and therefore sought to fortify the effects of, and by extension his authority over, religious interpretation.

In nineteenth-century Egypt, 'Abduh criticized the unbending nature of the two mentioned systems of knowledge transferral because they often produced results that had no place in a rapidly developing world infused by European science and technology. Here, Haj shows that 'Abduh's reformism was both a revivalist and a reformist project often labelled as a 'Salafiyyah movement'..$^{70}$ Both men attempted to refer to the original authoritative process of knowledge production (i.e., the Qur' an and Sunnah). ${ }^{71}$ According to her, the early traditions of interpretation and deduction of jurisprudential guidelines were state-of-theart methods that brought about socio-political (and therefore scientific) progress. Both of them were, so to speak, products of their respective 
times with all that that entails. In other words, "[a]s a Muslim reformer, 'Abduh, like Ibn 'Abdul Wahhab before him, was seeking to reconfigure "Islam" in order to both challenge and accommodate the changes in his age - in this case, to ensure the continuity of Islamic authority in the context of an overpowering colonial modernity'. ${ }^{72}$ The nature of both reformers' results is certainly open to debate. Their revivaltraditions have clearly developed into competing intellectual strains, both of which still draw the attention of contemporary Muslim social movements. ${ }^{73}$

One may argue that Haj's analysis runs contrary to al-Jabri's thesis of a restrained Arab reason by displaying the continuity of Islamic revivalism. After all, a-Jabri's critique of the outmoded epistemic foundation of Arab reason was premised on the assumption that the ArabIslamic thinking process contains a fundamental error related to its ability to conceptualize 'reality'. Hallaq and Haj are more nuanced in that respect, for they do not view the Islamic tradition as inherently flawed in this respect largely because they do not share al-Jabri's position on modernity - as the ultimate path of realizing social progress. Instead, their willingness to be more open about the unique set of circumstances and experiences that Muslim societies have endured, allows them to hold a broader conceptualization of modernity. What makes these circumstances and experiences unique, in comparison to the liberal tradition, is their deep attachment to Islam's religious text(s). Even so, Hallaq and Haj demonstrate that the Islamic tradition contains a great deal of room in which one can manoeuvre, despite its being rooted in a specific religious doctrine. ${ }^{74}$ In fact, Hallaq points out that Muslims and non-Muslims can gain quite a lot by considering many of the universal values found in the Islamic tradition and which are shared by the world's many cultures. ${ }^{75}$

Haj's analysis and comparison of the two reformers is somewhat unbalanced in content, perhaps because of the inconsistent depth of their ideas and legacy. In subsequent chapters, she explores the abundant writings on and by "Abduh that focus primarily on his attempt to reconstitute a Muslim subject. Although modernist at its core, this project cannot be considered 'liberal' in the sense of that word noted above. He was in fact a modernist, for he diligently tried to explicate commonalities between the modernist project and the Islamic tradition without insisting on the rupture between faith and reason. Instead, and 
contrary to the majority scholarly view, Haj argues that 'Abduh held that a Muslim could be both modern and live within the framework of moral law. He believed that 'the law continues to derive its authority from Islamic law (figh) and that religious authority ipso facto extends beyond the individual and the private sphere. 'Abduh presumed, as any Muslim would, that religious duties ('ibadat), as embodied practices, were constitutive of social relations, and he took for granted that interactive transactions (mu'amalat) were integral to the constitution of a Muslim subject'.$^{76}$

Moreover, Haj asserts that "Abduh "was vehemently against the dismantling of Islam as a regulator of social morality (via the institutions of the family and education). He opposed the [British] colonial administration for intending to dislodge religion from its public functions and insisting on creating a civic society in which morality is a private matter' ${ }^{77}$ Here, she encapsulates the dilemma that has faced Muslim thinkers ever since: the tension between espousing and rejecting the state-liberal conceptual framework and understanding of modernity. This reasoning is in line with much of Hallaq's analysis and even supports 'Abduh's thesis that the modern civil state, with its power to coerce populations through laws and other measures, is not compatible with the objectives of the Islamic tradition. He saw danger in the state's intrusion into, as well as its subsequent attempts to manipulate, public morality. Remarkably, 'Abduh's consideration lies at the centre of Hallaq's entire argument. The state is ontologically inclined toward controlling agency, which includes control over the forces that inspire agency, religion and ideology being some of the most powerful motivators for change. An important part of 'Abduh's reformist project was to redefine religious authority as a way of safeguarding Islam's moral principles from, in his case, colonial state intrusion. ${ }^{78}$

Ibn 'Abdul Wahhab's projected reformism followed a seemingly different path. Here, the morality of the Muslims' religious confession, important as it is, was subordinated to the external enactment of faith. ${ }^{79}$ The resistance of the religious establishments in Najd and elsewhere to his mission created a very different context than the one facing 'Abduh in nineteenth-century Cairo and al-Azhar's religious authority. As noted above, Ibn 'Abdul Wahhab's passionate insistence on correspondence between the Muslims' individual and communal behaviour with the 
tenants of tawhid (God's inimitable unity) created multiple tensions among his peers and with the surrounding social structures. He successfully allied himself with the local Sa'ud clan of the "Anaiza tribe, an alliance upon which the modern-day Kingdom of Saudi Arabia was established. ${ }^{80}$ In a way his reformism, or at least an interpretation of his project, resulted in a state and a global Muslim movement. ${ }^{81}$ The question that he brought to the fore of the revivalism-reformism debate, one that has remained the principal issue of the contemporary Salafiyya movement (in its various forms and shapes), is whether un-Islamic innovations are or are not the antithesis of 'authentic' Islamic faith and practice. $^{82}$

How this particular revivalist project fits into the framework of modernity is not entirely clear in Haj's analysis. Nevertheless, it reveals a part of these two religious scholars' ethical considerations. The discussion of 'Abduh's thought shows a high degree of synchronism of various cultural habits in approaching Islam, a reality that makes him far more contemporary in referring to Islamic references than previously believed. Here we see another side of his reformism, one that postulates a radical reinterpretation of various historical concepts designed to maintain their existing references to the Islamic tradition's fundamental sources. Ibn 'Abdul Wahhab's revivalist ethics is far more delineated and stringent in terms of interpretative procedures and thus functions within a narrow ethical range. Much like John Calvin, Ibn 'Abdul Wahhab's approach to the text is literal and social effects of his teaching are viewed as reactionary. ${ }^{83}$ Subsequently, both 'Abduh and Ibn 'Abdul Wahhab's revivalist projects encompassed processes of inserting and refuting various practices, habits, and ideas that developed outside of Islam's birthplace. Their respective efforts represent an example of a dynamic tradition that 'was able to both survive and remain Islamic'. ${ }^{84}$

\section{Conclusion}

The Islamic tradition has developed through a multi-layered discursive trajectory that has generated a sophisticated set of socio-political and religious abstractions. The abstraction and creation of the modern nation state does not emanate from this tradition. Despite this, the concept and 
application of state as the sovereign institution has been thoroughly integrated within the ongoing socio-political discourse of not only Muslim majority societies, but also globally. Hallaq rightly views this as something problematic for many noted reasons. But what is the alternative? Despite Hallaq's powerful critique of the concept of an Islamic state, Muslims today are regularly using, referring, and trying to build functioning state institutions. This is part of the conversation now taking place across Muslim communities. This is also a sign that the modern idea of the state has become an integral part of the contemporary Islamic tradition, regardless of the apparent paradox of an Islamic state. Similarly, Al-Jabri's line of reasoning does not help solve the suggested tensions between Greco-European inventions and 'Arab reason'. Although he provides us with a highly engaging, provocative, and dense analysis, it is difficult to find any workable solutions therein. He nonetheless suggests that 'Arabs' ought to discard a major part of their (Islamic) tradition in order to properly modernize. His argument can be summed up by Albert Camus' famous phrase: 'A tradition is a past that distorts the present' ${ }^{85}$ This 'solution' is worryingly deconstructive in the apparent meaning of the term and for the following reason: If one divorces a tradition's central theme, its 'essence' as it were, even in an attempt to improve it, is this not the same thing as obliterating the tradition itself, both 'good' and 'bad' therein? Al-Jabri's intellectual project goes far beyond reform; it actually seeks to strip the Islamic tradition of its unique feature by arguing that Arabs can enter modernity only if they dethrone their epistemic relationship with the Qur'an and Sunnah.

The entire idea of socio-political ethics in Muslim-majority societies in general, and in Arab societies in particular, is premised on the very thing that has formed their civilization: the Islamic tradition. All three authors frame their discussion on modernity on various parts of that tradition. To illustrate this, Haj's analysis points out the importance of tradition in any socio-political revival that departs from 'the text'. This does not mean that the text determines the debate's outcome; it merely suggests that explicit religious assertions are an integral part of the intellectual conversation. The implications of such a conversation have a public resonance that is often recognizable in terms of those cultural and socio-political ethical (discursive) practices that reveal the wider moral implications of the tension between Islam as a living tradition and the process(es) of modernity ${ }^{86}$ This idea of process within 
the scope of modernity suggests the possibility of multiple 'modernities' ${ }^{87}$ It is plausible to assume that we are in the middle of a process of formulating a new type of modernity, one that integrates a specific religious tradition with scientific progress, one in which specific religious principles provide more optimistic forms of human cooperation and where the focus on ethics shapes a more inclusive and morally conscious form(s) of governance. ${ }^{88}$ The article has discussed only a fragment of the dynamics of contemporary Muslim intellectual debates about modernity. Still, if we are to appreciate the implication of modernity discourses for broader Muslim communities today, we need to continue to deepen our empirical cognizance about the shared meanings of alternative, more morally conscious, ethically consistent, and optimistic forms of modernity.

\section{Notes}

I In this article, Islamic tradition signifies 'a discursive tradition [!] that includes and relates itself to the founding texts of the Qur'an and the Hadith. Islam is neither a distinctive social structure nor a heterogeneous collection of beliefs, artifacts, customs, and morals. It is a tradition.' Talal Asad, 'The Idea of an Anthropology of Islam', Occasional Papers Series, Center for Contemporary Arab Studies (Washington, DC, I986) I4.

2 This essay does not use the customary didactical marks for Arabic terms primarily because the authors of the reviewed books are inconsistent in this regard.

3 More lucidly, and much earlier, Asad argued that 'Islam as the object of anthropological understanding should be approached as a discursive tradition that connects variously with the formation of moral selves, the manipulation of populations (or resistance to it), and the production of appropriate knowledge'. Asad, 'The Idea of an Anthropology of Islam', 7.

4 Joris van Eijnatten et al., 'Shaping the Discourse on Modernity', International Journal for History, Culture and Modernity I (2012) 3-20, I 7.

5 Alasdair MacIntyre, Whose Justice? Which Rationality? (London, I988) I I .

6 See Rob Warner, Secularization and Its Discontents (London, 20 I0) 22-38.

7 Richard Khuri, Freedom, Modernity, and Islam: Toward a Creative Synthesis (Syracuse, NY, I998) xviii-Xx. 
8 John Stuart Mill, On Liberty and Other Essays, ed. J. Gray (New York, I99I) 472.

9 Charles Taylor, 'What's Wrong with Negative Liberty', Philosophy and the Human Sciences: Philosophical Papers 2 (Cambridge, I985) 2 I I-29.

Io Khuri, Freedom, Modernity, and Islam, xx.

I I Ibid., 37-40.

I 2 Ibid., 48-49.

I3 The terms West and western tradition are used here in the generic sense of various practices and intentions that have produced innumerable subsequent intentions, practices, and discourses in systematic ways. This is not to say that there is an integrated western culture, a fixed western identity, or even a single western way of thinking, for a singular collective identity defines itself in terms of a unique historicity in conflict.

I4 Alasdair Macintyre, Virtue: A Study in Moral Theory, 3d ed. (Notre Dame, IN, 2007) xii.

I 5 See George Hourani, Reason and Tradition in Islamic Ethics (Cambridge, I985); Wael B. Hallaq, The Origins and Evolution of Islamic Law (Cambridge, 2005); Khuri, Freedom, Modernity, and Islam.

I6 Kevin Reinhart, 'Origins of Islamic Ethics: Foundations and Constructions', in: William Schweiker (ed.), The Blackwell Companion to Religious Ethics (Malden, MA, 2005) 246-52; Ebrahim Moosa, 'Muslim Ethics?' in: Schweiker, The Blackwell Companion to Religious Ethics, 239-43.

I7 Khayr al-Din al-Tunisi, Aqwam al-Masalik li Ma'rifat Ahwal al-Mamalik (Tunis, I 867); Leon Carl Brown, trans. and ed., The Surest Path: The Political Treatise of a Nineteenth-Century Muslim Statesman (Cambridge, I967); Muhsin Mahdi, Ibn Khladun's Philosophy of History: A Study in the Philosophic Foundation of the Science of Culture (Kuala Lumpur, 2006) I 56-59; Hourani, Reason and Tradition in Islamic Ethics, 200.

I8 Al-Jabri, The Formation of Arab Reason, 26.

I9 Ibid., 3-5, 7-8.

20 Ibid., 6.

2 I Ibid., 9.

22 Ibid., 56.

23 Ibid., 77.

24 Ibid., 4I6.

25 The era of hadith codification is considered to have lasted from roughly the second half of the second century to the late third century AH. See also ibid., $70-78$. 
26 Ibid., 47.

27 Recent research has challenged some of these conclusions. For example, The Pew Research Center, 'Obama's Challenge in the Muslim World: Arab Spring Fails to Improve U.S. Image' (20I I), esp. chap. 2 and 3. Another work that critiques the 'Arab reason' thesis, broadly understood, and its weak ability to adapt, change, and even transcend history is Muhammad Qasim Zaman, The Ulama in Contemporary Islam: Custodians of Change (Princeton, 2002). Al-Jabri's insights are indirectly challenged through an empirically supported claim that the very people concerned with preserving the earlier knowledge and tradition (by which 'Arab reason' allegedly functions), namely, the Islamic religious scholars, are the ones leading the process of socio-religious reformation.

28 Al-Jabri, The Formation of Arab Reason, 422.

29 Ibid., 3I9, 424-26.

30 Ibid., 4I7, 423.

3 I Marshall Hodgson, The Venture of Islam: Conscience and History in a World Civilization. Vol. 2 (Chicago, I977) 90-9i.

32 Some of the more powerful evidence of this is presented by C. E. Bosworth, 'The Persian Impact on Arabic Literature,' in: A. F. L. Beeston et al. (eds), Arabic Literature to the End of Umayyad Period (Cambridge and New York, I983).

33 Hallaq, The Origins and Evolution of Islamic Law, I 23-48.

34 In many instances, Hegel argued that the (material side of) human history was an expression of a (nonmaterial) World Spirit. See, for instance, Georg W. F. Hegel, Lectures on the History of Philosophy, trans. E. S. Haldane and Frances H. Simson (Lincoln, I995) 69, I35, 228.

35 Al-Jabri, The Formation of Arab Reason, 26.

36 Ibid., 24.

37 If one were to sum up al-Jabri's broader methodology based on this particular book, it would be useful to consider it in a wider philosophical tradition, regardless of the assumption that he might have disapproved of doing so. Paul Tillich described what I believe to be the appropriate methodological tradition used by al-Jabri, either consciously or unconsciously: 'When critical method is modified in terms of the intuitional and dynamic methods we call it metalogical. It is logical in the sense that the orientation to pure rational forms, involved in the critical method is retained. It is metalogical because it goes beyond pure formalism in a double sense, on the one hand in that it apprehends the import inhering in the forms, on the other in that 
it sets up norms in an individual-creative way. The metalogical method is based in the critic-dialectical method.' Paul Tillich, What is Religion? (New York, I973) 50 (italics in the original).

38 See John Makdisi, 'Formal Rationality in Islamic Law and the Common Law', Cleveland State Law Review 34 (I985) 97-I I2. For anyone familiar with the legal history of the Islamic Middle East and North Africa, it is painstakingly obvious that the dynamic of jurisprudence allowed for deliberate confrontations between the religious scholars, thereby creating a whole range of legal methodologies and interpretations of the text. See Hallaq, The Impossible State, 55-56.

39 Hallaq, The Impossible State, I65-67.

40 Robert N. Bellah, Beyond Belief: Essays on Religion in a Post-Traditional World (New York, I970) I50-60.

4I Al-Jabri, The Formation of Arab Reason, 422

42 Malise Ruthven, Fundamentalism: The Search for Meaning (Oxford, 2004) 68, I68.

43 For a more elaborate argument, see Antoni Abramov, 'Ibn Taymiyya on the Agreement of Reason with Tradition', The Muslim World 82 (I992) 256-73, and Hodgson, The Venture of Islam, vol. 2, 47 I-72.

44 Moosa, 'Muslim Ethics?', 240.

45 A convincing refutation of the closed-door-of-ijtihad thesis is presented by Wael Hallaq, 'Was the Gate of Ijtihad Closed?', International Journal of Middle East Studies I6 (I984) 3-4I. A more technically elaborate argumentation can be found in Jasser Auda, Maqasid al-Shariah as Philosophy of Islamic Law: A Systems Approach (Herndon, VA, 2008) 46-48; see also, George F. Hourani, Reason and Tradition in Islamic Ethics (Cambridge, I985) I 5-22 and I48.

46 Aziz al-Azmeh, 'Islamist Revivalism and Western Ideologies', History Workshop 32 (I99I) 44-53, 47.

47 Armando Salvatore, 'The Reform Project in the Emerging Public Spheres', in: Muhammad Khalid Masud, Armando Salvatore, and Martin van Bruinessen (eds), Islam and Modernity: Key Issues and Debates (Edinburgh, 2009) I $85-88$.

48 Hallaq, The Impossible State, I-I 8.

49 Ibid., 5I. Here, sovereign carries the same meaning given to it by Carl Schmitt, namely: 'Sovereign is he who decides on the exception.' Carl Schmitt, Political Theology: Four Chapters on the Concept of Sovereign, trans. George Schwab (Cambridge, MA, I985 [I922]). 
50 Carl Schmitt, Political Romanticism, trans. Guy Oakes (Cambridge, MA, I986 [19I9]), 99. To be sure, Schmitt's critique was directed primarily toward the liberalism of the Weimar Republic-nevertheless, his claims are broad, insightful, and certainly relevant for the critique of liberalism today.

5 I Hallaq, The Impossible State, 70-73.

52 Here I claim that 'the instrumentality of reason' is, in many ways, a process by which public morality, in particular family and civil law, has been shaped throughout twentieth-century Europe.

53 Ibid., 78-82.

54 Ibid., I 33 (the italics are in the original).

55 Ibid., I38.

56 Ibid., I6-I7.

57 Ibid., 62.

58 Ibid., 70-73; Fazlur Rahman, Islam and Modernity: Transformation of an Intellectual Tradition (Chicago, I984) I60.

59 Hallaq, The Impossible State, 25-30.

60 Max Weber, From Max Weber (London, I948) 320-24.

6I George Fawaz, 'The new capitalists: Islamists' political economy,' Open Democracy, May I0, 20I2, www.opendemocracy.net/fawaz-gerges/newcapitalists-islamists-political-economy (accessed November I2, 20I3) (my italics).

62 Nader Habibi, 'The Economic Agendas and Expected Economic Policies of Islamists in Egypt and Tunisia', Middle East Brief, no. 67 (October 2012) 6.

63 Hallaq, The Impossible State, I68.

64 Theodor Adorno and the proponents of the Frankfurt School described capitalism as one of modernity's direct products and as based upon systematic inequality among groups of people, thus instrumentalizing human relations to the point of where reason becomes a mere instrument to maximize individuals' material wellbeing. Theodor W. Adorno, Negative Dialectics, trans. E. B. Ashton (London, I990). On the other hand, depending on an individual's intellectually contingent perspective, a phenomenon can be viewed as beneficial or detrimental. Al-Jabri would most likely consider capitalism as something inevitable and, most likely, something positive because modernity is inherently about, among other things, economic 'progress' and humanity's advancement.

65 Hallaq, The Impossible State, I57-I 58.

66 The crises here denote not only those disasters attributed to morally based governance vs. liberal positivism, but to all disasters (whether natural or 
man-made) irrespective of state boundaries and administrative responsibilities. See ibid., I69-70.

67 See al-Azmeh, 'Islamist Revivalism and Western Ideologies'; Majid Fakhry, A History of Islamic Philosophy. 3d ed. (New York, 2004) 345-68, 369-98; Reinhard Schulze, A Modern History of the Islamic World, trans. Azizeh Azodi (London, 2000)I4-60, I94-247.

68 There seems to be some confusion as to exactly when Ibn Abdul al-Wahhab died. Most sources use I79I; on page I 8 she indicates I787, which is not an insignificant difference.

69 Haj, Reconfiguring Islamic Tradition, 30-35.

70 Haj mentions 'Abduh in reference to the idea of Salafiyyah (pp. 69, 83, 86) in order to describe his reformist method: A contemporary Muslim should look to the early generations of pious Muslim scholars (salaf al-salih) for inspiration and guidance. This is a common mistake made by many contemporary academics due to their habit of relying on the soundness of previous scholarship. Recent historical research conducted by Henry Lauzière reveals that the term Salafiyyah, as used within the context of 'Abduh's reformist project, is actually a faulty posthumous construction of an otherwise competent French scholar of Islam: Louis Massignon (d. 1962). Lauzière explains that this attribution is most likely due to scholarly laxity, something that both modern-day orientalists and their critics have continuously reproduced. Henri Lauzière, 'The Construction of Salafiyya: Reconsidering Salafism from the Perspective of Conceptual History', International Journal of Middle East Studies 42 (2010) 369-70.

7I Haj, Reconfiguring Islamic Tradition, 66.

72 Ibid., 7I. Haj's claim that the two reformists intended to reconfigure Islam is perhaps too broad. As far as I understand their project, they were primarily concerned with reforming the Islamic tradition of interpretation (ijtihad) rather than with seeking the 'reconfiguration of Islam' itself. Nevertheless, Haj touches upon this elsewhere in the text (pp. I07, I IO).

73 See Masud, Salvatore and van Bruinessen, Islam and Modernity, 3-57, 8I-I04, I7I-I 76, I85-26I.

74 In this instance, it would be useful to compare Islamic tradition and the 'western' liberal tradition's epistemologies on communal and individual rights. We know that many scholars of the latter tradition consistently refer their understanding of rights back to the 'canonical' writings of Immanuel Kant, John Locke, John Stuart Mill, Adam Smith, and similar figures. This is indeed similar to various Muslim scholars' ijtihad and referral to the 'text'. 
75 Arguably, Hallaq's intention seems to be to bring morality back into the current socio-political debate as a reflective tool for today's politics where economic growth, with its devastating consequences, acts as the main guiding principle. Similarly, many works of the contemporary political philosopher Michael Sandel reflect these concerns; however, he bases them on a different set of references. See, for instance, his Public Philosophy: Essays on Morality in Politics (Cambridge, MA, 2005).

76 Haj, Reconfiguring Islamic Tradition, I I 2.

77 Ibid., I 26.

78 Ibid., 97-99.

79 Ibid., I I4.

80 Ibid., I7-I9.

8I See Roel Meijer (ed.), Global Salafism: Islam's New Religious Movement (New York, 2009).

82 Haj, Reconfiguring Islamic Tradition, 53; See also Emin Poljarevic, 'In Pursuit of Authenticity: Becoming a Salafi', Comparative Islamic Studies 8 (2012) I39-I64.

83 There are no known comparisons between Calvin and Ibn Abdul Wahhab's interpretative methodology; however, there are some interesting similarities in how they approached the religious sources. See, for instance, Harro Höpfl, The Christian Polity of John Calvin (Cambridge, I985) I79-84 and Paul Helm, John Calvin's Ideas (Oxford, 2004) 88-92.

84 Haj, Reconfiguring Islamic Tradition, 88.

85 Albert Camus, 'The New Mediterranean Culture', in: Lyrical and Critical Essays (New York, I970) I90.

86 See Hussein Ali Agrama, Questioning Secularism: Islam, Sovereignty, and the Rule of Law in Modern Egypt (Chicago, 2012).

87 Interestingly enough, I could not find the term modernities in my old college dictionary, The American Heritage Dictionary, $2 \mathrm{~d}$ college ed. (Boston, I985), or in other language reference works. This perhaps indicates our reluctance to consider the possibility of multiple modernities.

88 In his The Dark Side of Modernity (Cambridge, 20I3), Jeffrey C. Alexander presents a well-rounded survey that attempts to reveal modernity's negative aspects in order to problematize the common, long-held, and overly sympathetic understanding of this particular term. He informs students and theorists of modernity that they need to be equally aware of its positive and negative effects, as well as of the multitude of tensions it has (and continues to) produce and the potential (for sustainable progress) that it still holds. 


\section{About the Author}

Emin Poljarevic is a lecturer at the Department of Ethnology, History of Religions and Gender Studies at Stockholm University in Sweden. His main fields of interest are the sociology of Islam and social transformations of Muslim communities in Europe and the MENA region. He has published works on Islamist mobilization, Islamic history and nonviolent social activism. His forthcoming book, Islamist Grassroots and Youth Activism: A Sociology of the Muslim Brotherhood and Salafi Movement in Egypt, will be published by Ashgate Publishing Ltd. as a part of the mobilization series on social movements, protest and culture. Research underlying this article has been supported by the WennerGren Foundation. E-mail: emin.poljarevic@ @rel.su.se 